\title{
Albanian Economy: Proportional or Progressive Taxation?
}

\section{Ph.D Ejona Bardhi}

\author{
Professor at the Faculty of Law, University of Tirana, Albania
}

Email: ejona-87@hotmail.com

\section{Doi:10.5901/mjss.2017.v8n1p176}

\begin{abstract}
Choosing the best system of taxation lies in the balance between equality and fairness or efficiency. It is an expression that should guide any fiscal policy. Given that one of the hottest economic topics that pits the political parties can not stay away from the attention of citizens and scholars of the economy. On the one hand we have a tax that provides the same percentage for all categories of income, on the other hand you have a tax increase progressively in line with revenues. therefore, taxes less progressive taxation individuals with lower incomes, but if the tax burden shifted progressively to individuals with higher incomes, it remains to be discussed. Like most developing countries, Albania differs in many respects from developed countries, among which capacity institutional, state, rule of law, the structure of the economy and other economic characteristics. Such differences justify a different tax policy. Progressive taxation has been applied in Albania since 2015. Is this a tax that provides equality for all? Stated every moment and in every public appearance of our politicians, "equality before the law" as a principle that should be applied objectively and accurately reports, but this system offers true equality before the law? What has brought the Albanian economy this system? What happened to investments or unemployment? Through this work I intend to present a clear analysis of income tax applied in Albanian economic system and how this tax has affected the economy as a whole. Also this work is also a reflection on the advantages and disadvantages of this tax system.
\end{abstract}

Keywords: proportional tax, progressive tax, economic system, informality, advantages

\section{Introduction}

This essay will treat some pros and cons aspects of flat and progressive taxation, concluding that the flat taxation is the fairest one. We will treat the concepts of the two types of taxation, different opinions which circulate from the professionals of the field, hypothetical practical cases and at end the authors of this essay achieve an unified opinion. The essay aims to exit the theory frameworks where this debate lays todays and to argue on the current consequences that these types of taxes have on the societies of different countries.

\section{Flat Taxation}

What do you understand by the term "flat tax"?

"Flat tax" is translated as the tax on personal incomes, differently known as proportional tax. We have a mistake in practice between the term tax and fees on this case and this is due to the word in English "tax" which in this case is not translated as tax but fee. In other words, the flat fee consists in the payment of a continuous contribute in the state budged, concretely at the extent of $10 \%$. This mass is the same for every level of wage of state budged. In Albania, the flat fee originates in 2007 creating a growth of the state budged for the continuous years. incomes?

The question widely asked nowadays is: Is this fee fair for every type of population based on the economic

According to a group of analysts, this fee is favorable for the rich people and is heavy for the pockets of the poor people. Being that the percentage of the contribute is the same for everyone, This $10 \%$ is translated in proportional quantities which is heavier on a poor person who has less incomes than a rich person.

The flat taxation is considered as more favorable for the middle layer of population, but Albania maintains a large misbalance regarding the economic layers. The debate continues further on the choice between them.

The debate raised earlier in time and was an object of debated between different philosophers, such as Jean Baptiste, who raises some question:

"Isn't a contribution based on a same proportion heavier for the poor people? The man who produces bread only to maintain his family and himself alive, should contribute exactly at the same proportion as the one who thanks to his talent 
and inheritance not only pleases himself and his family for needs and pleasures, but also increases his wealth?"

\section{Progressive Taxation}

The Progressive tax structure is the one according to which upon the increase of tax base (incomes, expenses or wealth) is also increased the tax scale. Through it, it is aimed to decrease the effect of taxes for the people with law paying ability, displacing it in an non proportional manner to the people with higher paying ability. The main purpose of the progressive structure is triple:

1. To tax all as everyone benefit from the public goods produced by the state.

2. Those who gain the most must be taxed the most

3. Accumulates more financial resources in the hands of the state.

This taxation is seen, differently from the flat tax, as a blessing for the middle layer and the needy one. More than 300,000 employees are freed from the fiscal charge and more priority is given to the different fields such as: agriculture, education, health, social protection, pensions scheme etc. At the first view more incomes are accumulated. It is worth asking: Is the progressive tax system fair for the rich people? Several theories, admit that the purpose of the progressive system is not the penalization of the ones who manage, but the defense of the ones who cannot manage and the rich people pay more as they benefit more from the national incomes. In reality this taxation punished unfairly the people due to their success in the society. Not necessarily there is a fair proportion between the paying ability and benefit of public services. As it may happen that a rich person benefits less public services than a poor person, therefor it is considered as a form of double taxation of this layer of society. A disadvantage related to the application of the progressive taxation is the one which brings a greater and more severe fiscal burden for the business and corporations and as a consequence the latter are predisposed to hide their obligations, differently from the small business which blooms.

\section{Practical Case: Progressive Taxation and the History of the Three Brothers}

"Prager University", in order to clearly illustrate the disadvantages deriving from the layer with a better economic condition from the progressive taxation, brings into attention of the audience an animated video where it shows a hypothetical history on the application of this taxation.

In this animated video there appear three brothers. The three were raised upon the same possibilities, they had the same intellectual level, the three had the same profession: carpenter and were paid at the same wage, $25 \$$ working hour.

Nevertheless these similarities, they had different priorities in life.

The first brother choose to work 20 hours/ week and married a woman who did not work.

The second brother worked 40 / week and married a woman who worked part- time as real estate agent, and was paid $25.000 \$$ / year.

The third brother worked 60 hours. week and married a woman who worked full time and earned $50.000 \$ /$ year.

The two first brothers and their wives did not save during the working period thinking that they contributed for social security and it would be enough for their senility.

The third brother and his wife, having other priorities, saved each month and they periodically invested in shares of different commercial companies.

In this way, at the end of the year, the incomes of the three brother and their wives were as the following:

The incomes of the first brother were $25.000 \$$ / year.

The second brother 75.000 \$year

The third brother $150.000 \$$ / year

At a certain time the three brothers bought house at the same vicinity. After spending some time living there, they ascertained that the environment around needed some investments, such as the road should be asphalted, the view should be regulated, and a big gate should be placed in order to protect the area from criminality. All these investments had a cost of $30.000 \$$. In this moment it raised the problem of how this invoice should be divided.

The third brother suggested that the invoice should be divided in equal parts. As a consequence each of the bothers had to pay $\$ 10.000$ each. The two other brothers objected arguing that the third brother was richer and therefore he must pay more. The latter objected saying that he was in a better financial conditions because he worked more, not as the other two brothers, but they ignored it.

The second brother proposed another formula for the division of the invoice. He ascertained that the mutual incomes of the three brothers, were $250.000 \$$ and the invoice of $30.000 \$$ was $12 \%$ of this amount. Therefore, according 
to the second brother, each of the brothers should pay 12 \&of his annual incomes, and the invoice should have been divided in this manner

Third brother: $18.000 \$$

Second brother: $9.000 \$$

First brother: $3.000 \$$

The first brother said that he had a better idea and fairer according to him. He proposed that the third brother paid 23.000 \$, the second brother 7.000 \$ and he did not pay at all.

The second brother though this opinion was completely arbitrary but he followed his interest. Pursuant this formula he would pay 2.000 \$ less than with his formula.

The other brother, which was the richest, objected saying that he did not understand why he should pay almost 80 $\%$ of the fee when all of them benefited equally from the investments.

The proposer explained that this was the federal tax system of USA (their country) and they shouldn't act differently.

As a consequence voting 2 against 1 it was decided that the formula to be followed was the third one. The two dominating brothers, liked this formula so much that they decided to apply in other investments as well.

\section{Points for Reflections and Conclusions}

The above case indicates that the saying "the progressive tax punishes the rich people" has a side of the medallion which is not treated mainly from the ones who defend it as taxation philosophy. It is often forgotten that these rich people may be people with ordinary jobs who choose to work harder than others, to risk more (such as the case of the third brother who worked harder, saved and risked by investing in capital companies).

The metaphor of investments in vicinity we treated, represents in fact the public benefits from taxation. As in the case of the three brothers, and the real life, the benefits that different individuals obtain is the same, nevertheless how much they have invested. this fact makes the rich part of the population fairly even more parsimonious.

it is known the expression "the progressive taxation does not punish the rich but help the poor." We think that this justification is nothing more but a game of words. Further than justification philosophies, we should bring into attention the negative impacts of this taxation.

Firstly, it makes the rich layers of the population to hide the incomes, known as fiscal evasion. Despite the fact that the rich population is directed to the perpetration of an offence, this brings economic block. The rich people would not declare their incomes and would not invest them, and as a consequence the currency would not circulate in the country in order to obtain an economic growth.

Secondly, the rich people, would be directed to moral hazard, dishonest behavior. In this form the rich would put their wealth in the name other people so they were not taxed as they would be normally taxed. These actions are regular in the first view but they constitute actions in fraud of the law.

thirdly, the investments would be decreased significantly, and this is not a disadvantage only for rich people, but also for the middle layer and the poor layer of the population. Fewer investments mean fewer job positions.

\begin{tabular}{|l|l|l|}
\hline & Flat Tax & Progressive tax \\
\hline Advantages & $\begin{array}{l}\text { - Identifies the businesses and puts them before } \\
\text { the predisposal to pay the obligation }\end{array}$ & $\begin{array}{l}\text { - Brings more incomes in the state budged } \\
\text { - Helps the blooming of the small business }\end{array}$ \\
\hline Disadvantages & $\begin{array}{l}\text { - The businesses have more incomes to manage } \\
\text { - Prings less incomes for the state budged } \\
\text { funds }\end{array}$ & $\begin{array}{l}\text { - It is a harder fiscal burden for the businesses and } \\
\text { corporations }\end{array}$ \\
& - The businesses are predisposed to hide their obligations \\
\hline
\end{tabular}

Another speculation we think it is made, it the saying that the poor and rich cannot pay at the same manner. The flat taxation is based on the certain percentage on every individual which has incomes, but this percentage is not reflected in the same amount on each income. The concrete case is the one we treated above, the idea where each of the brothers should pay $12 \%$ of his incomes, but that this percentage was reflected differently in concrete amounts of money. In this framework, we can say that the flat taxation has progressive character, as it may appear that the same percentage is paid, but in reality the rich pay more.

Also, this taxation is not negative in its wholeness. We argue against it, imagining mainly the consequences which come in countries such as Albania or other countries in development. This taxation was successful is many developed 
countries, such as Scandinavian countries. The population in these countries admits that the taxes are very high, but justify what they pay, due to the fact that they see pleasant results in public services. Therefore the keys of functioning without problems of this taxation manner are:

Firstly, they will be used in solid economies and secondly the taxes will be used maximally. At the contrary there will appear consequences as above. We remind that USA as one of the most powerful economies in the work uses this kind of taxation, and the population is not pleased by it. We also bring into attention that this taxation is initiated by Marxist ideologies which are widely accepted to be utopic and not applicable.

\section{References}

Prager University, "Progressive income tax: A Tale of three brothers", video

Gjyli, Kristaq "takse e sheshte apo taske progressive"

Gazeta Shekulli, "Taksimi progresiv mbron shtresen e mesme"

Xhani, Dajana "Taksa progressive, disa argumente pro dhe kunder"

Fehlinger, G. Ramadani, A. "Taksa mbi te ardhurat personale, duhet te jete progressive apo e sheshte?"

Revista Monitor, "E sheshte apo progressive?"

ABC News (website) "Taska e sheshte e ben Shqiperine me Konkurruese" 